\title{
Mortality of motorcyclists due to traffic injuries in Brasil: a population-based study in Brazilian capitals
}

(iD) Carlos Dornels Freire de Souza ${ }^{1}$

(iD) João Paulo Silva de Paiva ${ }^{1}$

(iDThiago Cavalcanti Leal'

(D) Leonardo Feitosa da Silva'

(D) Gibson Barros de Almeida Santana ${ }^{1}$

(D) Divanise Suruagy Correia ${ }^{2}$

(iD) Michael Ferreira Machado ${ }^{1}$

(iD) Roberto Andrade Medronho ${ }^{3}$

(iD) Victor Santana Santos ${ }^{4}$

(D) Mônica de Avelar Figueiredo Mafra Magalhães ${ }^{5}$

1. Núcleo de Estudos em Medicina Social e Preventiva. Departamento de Medicina. Universidade Federal de Alagoas, Arapiraca, AL, Brasil. 2. Faculdade de Medicina. Universidade Federal de Alagoas, Maceió, AL, Brasil. 3. Instituto de Estudos em Saúde Coletiva. Universidade Federal do Rio de Janeiro, RJ, Brasil. 4. Núcleo de Epidemiologia e Saúde Pública. Departamento de Enfermagem. Universidade Federal de Alagoas, Arapiraca, AL, Brasil. 5. Instituto de Comunicação e Informação Científica em Saúde (ICICT), Fundação Oswaldo Cruz (Fiocruz), Rio de Janeiro, RJ, Brasil.

\section{SUMMARY}

OBJECTIVE: To analyze the mortality trend of young men who were victims of traffic injuries involving motorcycles in all Brazilian capitals from 2001 to 2015.

METHODS: A time-series study on all deaths of men aged 20-39 years old due to traffic injuries involving motorcycles in all 27 Brazilian capitals. We used the joinpoint regression model for temporal analysis and calculated the Annual Percent Change (APC) and Average Annual Percent Change (AAPC) to verify the mortality trends.

RESULTS: A total of 12,058 deaths of young men were recorded in the Brazilian capitals during the period studied. The highest mortality rates were observed in Boa Vista/Roraima (34.0/100,000 population) and Palmas/Tocantins (29.80/100,000). Twelve of the 27 capitals showed an increasing trend in mortality, with the highest percentage increase being observed in Salvador (APC: 29.0\%) and São Paulo (APC: $13.1 \%)$. None of the capitals showed a decline in the trend of mortality.

CONCLUSIONS: Overall, the mortality of young men from traffic injuries involving motorcycles shows an increasing trend in 12 of the 27 capitals, which represents a public health problem that requires the implementation of more effective public policies.

KEYWORDS: Accidents, traffic. Mortality. Epidemiology. Public Health. Motorcycles.

DATE OF SUBMISSION: 26-Feb-2020

DATE OF ACCEPTANCE: 22-Mar-2020

CORRESPONDING AUTHOR: Carlos Dornels Freire de Souza

Departamento de Medicina, Rodovia AL-115, s/n, Bom Sucesso, AL, Brasil - 47300-000

Tel: +55 87 99622-0698.

E-mail: carlos.freire@arapiraca.ufal.br 


\section{INTRODUCTION}

Mortality due to traffic injuries has become a public health problem worldwide'. In 2016, traffic caused about 1.35 million deaths, representing the eighth global cause of mortality ${ }^{1,2}$. Of these deaths, $50 \%$ were of individuals considered more vulnerable (pedestrians, cyclists, and motorcyclists), and young men constituted the risk group ${ }^{1,2}$.

In 2016, Brasil registered 37,345 deaths resulting in a mortality rate of 18.1/100,000 population ${ }^{3}$, and it was one of the five countries with the highest traffic-related mortality, alongside India, China, USA, and Russia ${ }^{1}$. An estimated 4.6 billion dollars are spent annually on traffic-related deaths and injuries in Brasil ${ }^{4}$.

Because of the high number of deaths due to traffic injuries, the World Health Organization (WHO) attributed the period of 2011-2020 as the "Decade of Action for Road Safety" with the goal of halving mortality from traffic injuries in the world ${ }^{5}$. Brasil has implemented the National Injury Reduction Plan, which involves strategic actions to improve road safety and reduce the occurrence of traffic injuries and deaths ${ }^{6}$. Since Brasil is a country of continental dimensions with marked socioeconomic disparities, studies are needed to assess the behavior of the trend of mortality from traffic injuries, especially with population groups at increased risk of death. In addition, investigations into how mortality rates behave can support public strategies and policies aimed at road safety ${ }^{7}$.

This study investigated the mortality trend of young men who were victims of traffic injuries involving motorcycles in all Brazilian capitals from 2001 to 2015 .

\section{METHODS}

This was a time-series study including all deaths of young men aged 20 to 39 years old due to traffic injuries involving motorcycles that occurred in the 27 state capitals of Brasil from 2001 to 2015.

Data on the population were obtained from the Brazilian Institute of Geography and Statistics (IBGE). Data on the deaths were obtained from the Mortality Information System (SIM, in Portuguese) (http:// www2.datasus.gov.br). All deaths of young men with the International Classification of Diseases (ICD-10) codes V2O-V29 were included. The mortality rate was calculated by dividing the number of deaths of men aged 20-39 years old by the population of men aged 20-39 years old per 100,000 population. Data were obtained by year for each of the state capitals of the country.

The temporal trend analysis was calculated using the joinpoint regression model (Joinpoint Regression Program 4.5.0.1, National Cancer Institute, USA) with Monte Carlo permutations and error autocorrelation based on date. This method allows identifying trends and change points and determining the Annual Percentage Changes (APC) and overall period (Average Annual Percent Change - AAPC). Trends were categorized as stable, increasing, or decreasing ${ }^{8}$. We considered a 95\% confidence interval (95\% CI) and 5\% significance for all analyses.

The study did not require approval from an ethics committee as the databases are in the public domain without individual identifiers.

\section{RESULTS}

A total of 12,058 deaths of men aged 20 to 39 years old due to traffic injuries involving motorcycles were recorded in the Brazilian capitals from 2001 to 2015 . This corresponds to $17 \%(12,058 / 71,090)$ of deaths across the country in the period. The mortality rate in the capitals went from 5.52/100,000 ( $\mathrm{n}=394$ deaths) in 2001 to $12.32 / 100,000$ in 2015 ( $\mathrm{n}=107$ deaths) (AAPC $6.8 \%$; 95\% CI 4.8 to 8.9 ; P $<0.01$ ) (Figure 1). In 2001, 12 capitals had mortality rates higher than the national $(6.84 / 100,000)$. In 2015, eight capitals had a higher mortality rate than the national rate $(18.33 / 100,000)$. When considering the entire period (2001-2015), eight capitals stood out with rates higher than the national rate (14.80/100.00), two from the Northern region (Boa Vista/Roraima and Palmas/Tocantins), two from the

FIGURE 1. TIME TREND OF THE MORTALITY RATE OF MEN 20-39 YEARS OLD DUE TO TRAFFIC INJURIES INVOLVING MOTORCYCLES, PER BRAZILIAN CAPITALS FROM 2001-2015.

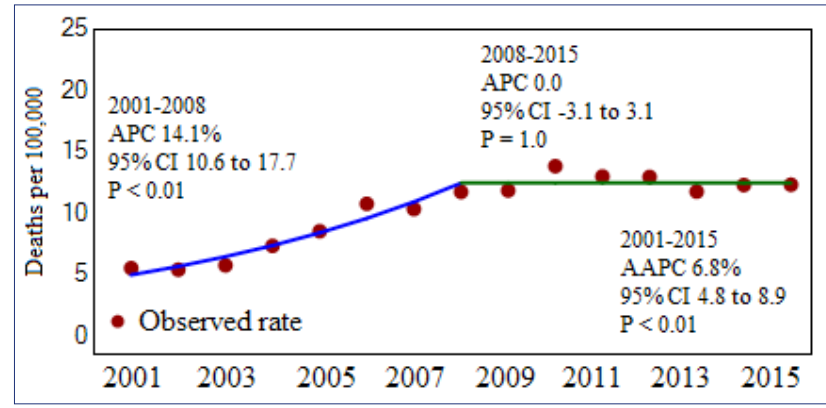


Northeast (Teresina/Piauí and Aracaju/Sergipe), three in the Central-West (Goiânia/Goiás, Cuiabá/Mato Grosso and Campo Grande/Mato Grosso do Sul), and one in the South (Florianópolis/Santa Catarina). The highest mortality rates were observed in Boa Vista/ Roraima (34.00/100,000 population) and Palmas/ Tocantins $(29.80 / 100,000)$ (Figure 2).

Twelve of the 27 Brazilian capitals showed an increasing trend, three in the North, five in the
Northeast, two in the Southeast and two in the Central West. The largest increase in mortality rate was detected in Salvador/Bahia (AAPC: 29.0\%; $\mathrm{p}<0.001$ ), with a mortality rate varying from $0.4 / 100,000$ in 2001 to $9.4 / 100,000$ in 2015, followed by São Paulo/São Paulo (AAPC: 13.1\%; $\mathrm{p}<0.001$ ), with a rate going from 4.4 to $11.1 / 100,000$ from 2001 to 2015 . None of the capitals had a decreasing trend (Table 1). The absence of death records in different years of the time series

FIGURE 2. MORTALITY RATES IN YOUNG MEN 20-39 YEARS OLD DUE TO TRAFFIC INJURIES INVOLVING MOTORCYCLES, PER BRAZILIAN CAPITALS FROM 2001-2015.
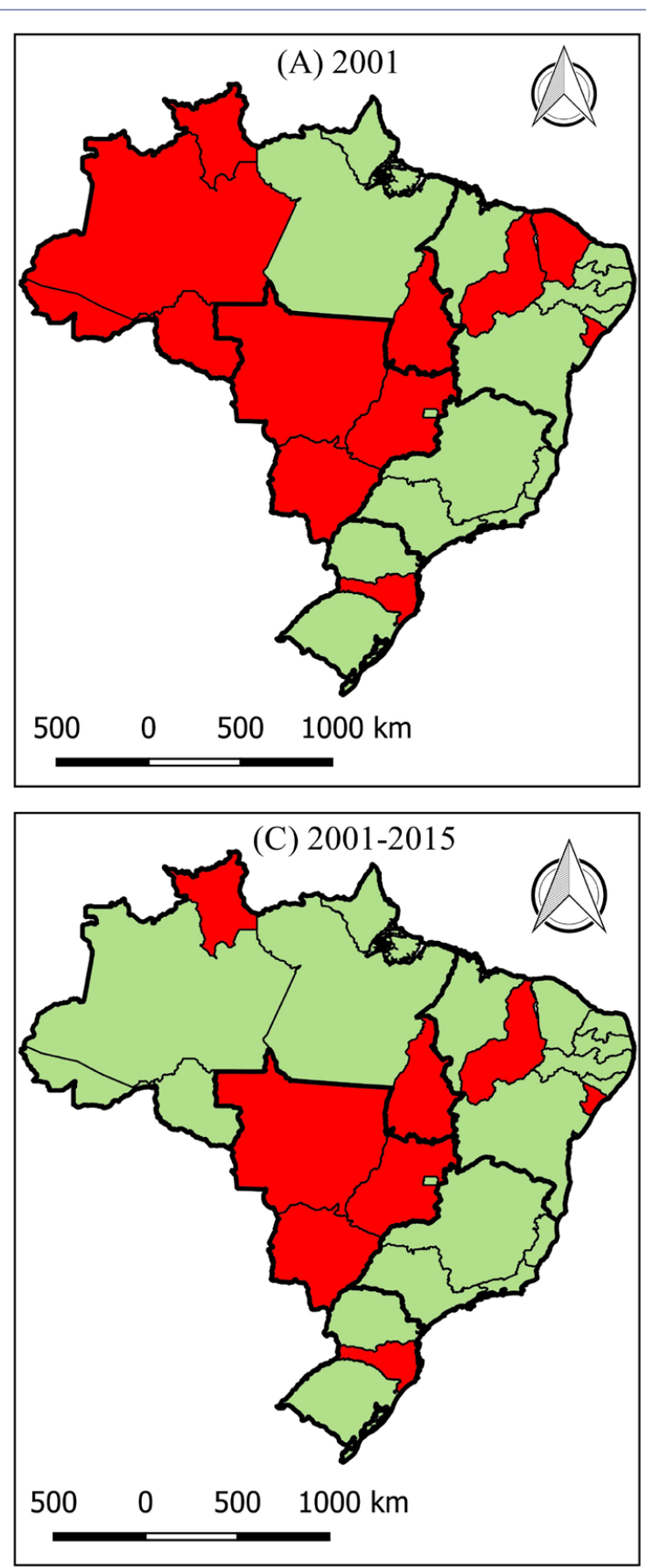

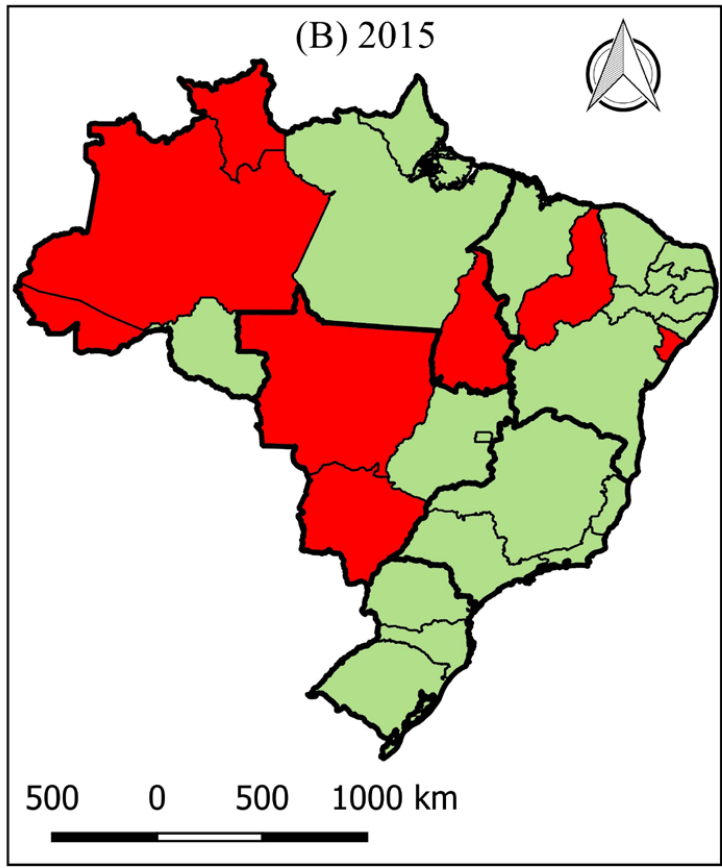

Mortality rates trend in young men (20-39 years) old due to traffic injuries involving motorcycles, by Brazilian capitals from 2001-2015

\section{$\square$ Regions}

Classification

Lower rate than national

Higher rate than the national 
in Rio Branco/Acre (2003, 2006, and 2008-2011) and Macapá/Amapá (2011) made the application of segmented regression unfeasible. Rio Branco/Acre and Macapá/Amapá registered 74 and 68 deaths in the period, respectively (Table 1 ).

\section{DISCUSSION}

Brasil has experienced a change in its morbidity and mortality profile in recent decades, with a considerable increase in deaths from chronic diseases and external causes (interpersonal violence and traffic injuries) ${ }^{9-11}$. In this study, we investigated the deaths of a population group at a higher risk of death (young men aged 20-39 years) due to traffic injuries involving motorcycles to identify the behavior in a 15-year time series in Brazilian capitals. Our findings call attention to the increasing trend in mortality, even in the period after the introduction of an emergency plan to reduce traffic-related deaths.

In view of this finding, some explanations are offered. Factors such as tax incentives for the installation of industrial motorcycle manufacturing centers, combined with the increased purchasing power of the Brazilian population and easier access to credit, resulted in an expansion in the number of motorcycles, not only in absolute numbers, but also in comparison with other vehicles ${ }^{9,12}$. In 1990, for example, the

TABLE 1. TREND OF MORTALITY RATES IN YOUNG MEN AGED 20-39 YEARS OLD DUE TO TRAFFIC INJURIES INVOLVING MOTORCYCLES, PER BRAZILIAN CAPITALS FROM 2001 TO 2015.

\begin{tabular}{|c|c|c|c|c|}
\hline Capital & Period & $\operatorname{APC}(95 \% \mathrm{CI})$ & AAPC $(95 \% \mathrm{Cl})$ & Trend \\
\hline Porto Velho/Rondônia & 2001-2015 & $10.5^{a}(5.2 ; 16.0)$ & $10.5^{\text {a }}(5.2 ; 16.0)$ & Increasing \\
\hline Rio Branco/Acre & $-\mathbf{b}$ & $-\mathbf{b}$ & $-\mathbf{b}$ & $-\mathbf{b}$ \\
\hline Manaus/Amazonas & 2001-2015 & $6.0^{\text {a }}(2.7 ; 9.5)$ & $6.0^{a}(2.7 ; 9.5)$ & Increasing \\
\hline Boa Vista/Roraima & $\begin{array}{l}2001-2003 \\
2003-2007 \\
2007-2015\end{array}$ & $\begin{array}{l}-65.9(-89.3 ; 8.9) \\
47.0(-17.7 ; 162.5) \\
-0.9(-12.7 ; 12.5)\end{array}$ & $-4.8(-22.3 ; 16.7)$ & Stable \\
\hline Belém/Pará & $2001-2015$ & $11.2^{a}(5.3 ; 17.6)$ & $11.2^{a}(5.3 ; 17.6)$ & Increasing \\
\hline Macapá/Amapá & $-\mathbf{b}$ & $-\mathbf{b}$ & $-\mathbf{b}$ & $-\mathbf{b}$ \\
\hline Palmas/Tocantins & $2001-2015$ & $-2.0(-4.5 ; 0.7)$ & $-2.0(-4.5 ; 0.7)$ & Stable \\
\hline São Luís/Maranhão & 2001-2015 & $6.2^{\mathrm{a}}(3.0 ; 9.6)$ & $6.2^{\mathrm{a}}(3.0 ; 9.6)$ & Increasing \\
\hline Teresina/Piauí & 2001-2015 & 11.5 a $(8.5 ; 14.6)$ & 11.5 a $(8.5 ; 14.6)$ & Increasing \\
\hline Fortaleza/Ceará & 2001-2015 & $-0.3(-3.4 ; 2.9)$ & $-0.3(-3.4 ; 2.9)$ & Stable \\
\hline Natal/Rio Grande do Norte & 2001-2015 & $4.1(-1.8 ; 10.4)$ & $4.1(-1.8 ; 10.4)$ & Stable \\
\hline João Pessoa/Paraíba & 2001-2015 & $10.0^{\text {a }}(4.1 ; 16.2)$ & $10.0^{\text {a }}(4.1 ; 16.2)$ & Increasing \\
\hline Recife/Pernambuco & 2001-2015 & $9.3^{\mathbf{a}}(4.9 ; 13.9)$ & $9.3^{\text {a }}(4.9 ; 13.9)$ & Increasing \\
\hline Maceió/Alagoas & $2001-2015$ & $0.7(-4.6 ; 6.4)$ & $0.7(-4.6 ; 6.4)$ & Stable \\
\hline Aracaju/Sergipe & 2001-2015 & $6.9^{\mathrm{a}}(3.8 ; 10.1)$ & $6.9^{\mathrm{a}}(3.8 ; 10.1)$ & Stable \\
\hline Salvador/Bahia & 2001-2015 & $29.0^{\text {a }}(16.2 ; 43.2)$ & $29.0^{a}(16.2 ; 43.2)$ & Increasing \\
\hline Belo Horizonte/Minas Gerais & $2001-2015$ & 6.9 a $(2.3 ; 11 ; 7)$ & 6.9 a $(2.3 ; 11.7)$ & Increasing \\
\hline Vitória/Espiríto Santos & $2001-2015$ & $0.3(-6.2 ; 7.4)$ & $0.3(-6.2 ; 7.4)$ & Stable \\
\hline Rio de Janeiro/Rio de Janeiro & $\begin{array}{l}2001-2009 \\
2009-2012 \\
2012-2015\end{array}$ & $\begin{array}{l}16.3^{\mathrm{a}}(8.9 ; 24.1) \\
-33.0(-63.2 ; 21.9) \\
29.8(-3.8 ; 75.2)\end{array}$ & $5.8(-6.5 ; 19.6)$ & Stable \\
\hline São Paulo/São Paulo & $2001-2015$ & $13.1^{\mathbf{a}}(5.7 ; 21.0)$ & $13.1^{\text {a }}(5.7 ; 21.0)$ & Increasing \\
\hline Curitiba/Paraná & $\begin{array}{l}2001-2006 \\
2006-2015\end{array}$ & $\begin{array}{l}39.0 \text { a }(6.4 ; 81.7) \\
-5.1(-14.9 ; 5.9)\end{array}$ & $8.8(-2.0 ; 20.7)$ & Stable \\
\hline Florianópolis/Santa Catarina & $2001-2015$ & $1.6(-3.2 ; 6.5)$ & $1.6(-3.2 ; 6.5)$ & Stable \\
\hline Porto Alegre/Rio Grande do Sul & $2001-2015$ & $2.9(-0.3 ; 6.2)$ & $2.9(-0.3 ; 6.2)$ & Stable \\
\hline Campo Grande/Mato Grosso do Sul & $\begin{array}{l}2001-2008 \\
2008-2015\end{array}$ & $\begin{array}{l}28.4 \text { a }(14.6 ; 43.8) \\
-4.6(-14.8 ; 6.8)\end{array}$ & $10.7^{\text {a }}(3.1 ; 18.7)$ & Increasing \\
\hline Cuiabá/Mato Grosso & $2001-2015$ & $4.5(-0.4 ; 9.6)$ & $4.5(-0.4 ; 9.6)$ & Stable \\
\hline Goiânia/Goiás & $\begin{array}{l}2001-2004 \\
2004-2015\end{array}$ & $\begin{array}{l}20.4(-2.7 ; 49.0) \\
-1.7(-4.5 ; 1.2)\end{array}$ & $2.7(-1.8 ; 7.4)$ & Stable \\
\hline Brasília/Distrito Federal & $\begin{array}{l}2001-2007 \\
2017-2015\end{array}$ & $\begin{array}{l}30.8^{a}(12.3 ; 52.2) \\
-4.3(-13.2 ; 5.6)\end{array}$ & $9.4^{\mathrm{a}}(1.5 ; 18.0)$ & Increasing \\
\hline
\end{tabular}

Legend: a Statistical significance $(P<0.05)$; ${ }^{b}$ Inconsistent data made the temporal analysis unfeasible; APC: Annual Percent Change; AAPC: Average Annual Percent Change. 
Brazilian fleet of motorcycles was 1.5 million and in 2014 this number reached 22 million units circulating in the country ${ }^{13}$. Also, the main consumers of these vehicles are young men, with lower purchasing power and low educational level ${ }^{14,15}$.

In the North and Northeast regions, the expansion in the number of motorcycles was even more intense. In the North region, the motorcycle fleet increased from 224,150 in 2001 to $1,757,003$ in 2015, accounting for an increase of around $684 \%{ }^{16}$. In the Northeast region, the motorcycle fleet varied from 766,886 in 2001 to $5,825,032$ in 2015, which represents an increase of nearly $660 \%{ }^{16}$. In this study, the three capitals with the highest rates were observed in the North (Boa Vista/Roraima and Palmas/Tocantins) and Northeast (Teresina/Piauí) areas. In Teresina/Piauí, 84\% of victims of traffic injuries assisted by the Emergency Ambulance Service in 2009 were involved in motorcycle injuries and $76 \%$ of these individuals were men ${ }^{17}$.

Other factors can play an important role when associated with the significant increase in motorcycles, such as: precarious conditions of roads and highways, deficiencies in traffic inspection, and lack of structural adaptations on highways and cities ${ }^{11,15}$.

In large cities or metropolises, the increase of the motorcycle fleet occurs both from the low cost of acquiring and maintaining the vehicle and from the speed of travel that the motorcycle promotes when compared to other vehicles, especially in the face of tumultuous traffic in these cities ${ }^{17,18}$. On the other hand, the increase in flow at peak times associated with structural deficiencies in the roads, deficits in the inspection mechanisms, and tiredness/fatigue of drivers create a scenario determinant to the occurrence of injuries involving motorcyclists ${ }^{18}$.

Motorcycles have taken on a new role in Brazilian society and in many other low- and middle-income countries. The motorcycle went from a leisure vehicle used on weekends to a working instrument for thousands of individuals ${ }^{11}$. The professions of motorcycle courier and motorcycle taxi and, more recently the delivery of parcels by apps, can have substantial impacts on the occurrence of injuries involving motorcyclists ${ }^{9,11,19}$. Studies on the working conditions of motorcycle couriers have shown that the indiscriminate demand for services causes them to institute an exacerbated work rhythm that leads them to violate traffic laws in order to be able to fulfill deliveries in a timely manner ${ }^{20}$. In addition, these professionals largely neglect the use of personal protective equipment ${ }^{19}$.
This process is potentially influenced by the working relationship to which these professionals are exposed ${ }^{19}$. As both motorcycle taxis and motorcycle couriers are self-managed, they have no formal employment relationship and their financial gain is dependent only on their work capacity, which results in an intensification of the workday in the search for compensation for the low added value of each task completed $^{19,20}$.

Even with methodological care, this study has the following limitations: i) use of secondary data whose quality can be questioned; ii) the inadequate filling out of the death certificate (DO) with the presence of the garbage code, and cases that occurred in hospitals whose underlying cause was not registered as a motorcycle injury; and iv) the underreporting of deaths.

\section{CONCLUSION}

The context shown in this study is worrying. Twelve of the 27 capitals showed an increasing trend in mortality. We advocate that broad public policies that include multisectoral actions, strengthening and guaranteeing the application of traffic legislation, structural improvements in the Brazilian road network, and consistent educational actions can contribute to the reduction of the problem in Brasil.

\section{Financial Support}

This study did not receive any financial support.

\section{Conflict of interest}

The authors have no conflict of interest to declare.

\section{Author's Contribution}

Carlos Dornels Freire de Souza, Leonardo Feitosa da Silva, Thiago Cavalcanti Leal, João Paulo Silva de Paiva, Gibson Barros de Almeida Santana: Participated in the development of the concept, planning of the study, data collection and analysis, discussion of the results, scientific writing, as well as in the review and approval of the final version of the work.

Michael Ferreira Machado, Maria Deysiane Porto de Araújo, Divanise Suruagy Correia, Roberto Andrade Medronho, Victor Santana Santos, Mônica de Avelar Figueiredo Mafra Magalhães: Participated in the writing of the results, discussion, scientific writing, as well as in the review and approval of the final version of the work. 


\section{RESUMO}

OBJETIVO: Analisar a tendência temporal da mortalidade de homens jovens vítimas de acidente de trânsito envolvendo motocicletas em todas as capitais brasileiras de 2001 a 2015.

MÉTODOS: Estudo de séries temporais incluindo as mortes de homens de 20 a 39 anos por lesões no trânsito envolvendo motocicletas nas 27 capitais brasileiras. Para a análise, foi utilizado o modelo de regressão do ponto de inflexão e calculada a Variação Percentual Anual (APC) e a Variação Percentual Anual Média (AAPC).

RESULTADOS: Foram registradas 12.058 mortes de homens jovens nas capitais brasileiras durante o período estudado. As maiores taxas de mortalidade foram observadas em Boa Vista/Roraima (34,0/100.000 habitantes) e Palmas/Tocantins (29,80/100.000). Doze capitais apresentaram tendência crescente de mortalidade, sendo o maior aumento percentual em Salvador (APC: 29,0\%) e São Paulo (APC: 13,1\%). Nenhuma das capitais mostrou declínio nas taxas.

CONCLUSÕES: A mortalidade de jovens por lesões no trânsito envolvendo motocicletas tem mostrado uma tendência crescente em 12 capitais, o que representa um problema de saúde pública que requer a implementação de políticas públicas mais eficazes.

PALAVRAS-CHAVES: Acidentes de trânsito. Mortalidade. Epidemiologia. Saúde pública. Motocicletas.

\section{REFERENCES}

1. World Health Organization. Global status report on road safety 2018 Geneva: World Health Organization; 2018. [cited 2019 Mar 23]. Available from: http://www.who.int/iris/handle/10665/276462

2. Organização Pan-Americana de Saúde. Folha informativa: acidentes de trânsito. Brasília: Organização Pan-Americana de Saúde; 2019. [cited 2019 Mar 23]. Available from: https://www.paho.org/bra/index.php?option=com_content\&view=article\&id=5147:acidentes-de-transito-folha-informativa\&Itemid $=779$

3. Observatório Nacional de Segurança Viária. Relatório anual 2017. Indaiatuba: Observatório Nacional de Segurança Viária; 2017. [cited 2019 Mar 23]. Available from: https://www.onsv.org.br/relatorios-anuais/

4. Observatório Nacional de Segurança Viária. Retrato da segurança viária no Brasil - 2017. Indaiatuba: Observatório Nacional de Segurança Viária; 2017. 104p. [cited 2019 Mar 23]. Available from: https://www.ambev.com.br/ conteudo/uploads/2017/09/Retrato-da-Segurança-Viária_Ambev_2017.pdf

5. World Health Organization. Global status report on road safety: time for action. Geneva: World Health Organization; 2009. [cited 2019 Mar 23]. Available from: https://www.who.int/violence_injury_prevention/ road_safety_status/2009/en/

6. Associação Nacional de Transportes Públicos. Década de ação pela segurança no trânsito - 2011-2020. Resolução ONU N² 2, de 2009. Proposta do Brasil para redução de acidentes e segurança viária. Publicada em 2 de março de 2010. [cited 2019 Mar 23]. Available from: https://www.nossasaopaulo. org.br/portal/arquivos/DECADA-2011-2020-PropostaBRASIL.pdf

7. Antunes JLF, Cardoso MRA. Uso da análise de séries temporais em estudos epidemiológicos. Epidemiol Serv Saúde. 2015;24(3):565-76.

8. Kim HJ, Fay MP, Feuer EJ, Midthune DN. Permutation tests for joinpoint regression with applications to cancer rates. Stat Med. 2000;19(3):335-51.

9. Bachierri G, Barros AJD. Acidentes de trânsito no Brasil de 1998 a 2010: muitas mudanças e poucos resultados. Rev Saúde Pública. 2011;45(5):949-63.

10. Souza CDF, Machado MF, Quirino TRL, Leal TC, Paiva IPS, Magalhães APN, et al. Padrões espaciais e temporais da mortalidade de motociclistas em estado do nordeste brasileiro no século XXI. Cien Saude Colet. [cited 2020 Jan 30]. Available from: em: http://www.cienciaesaudecoletiva.com.br/ artigos/padroes-espaciais-e-temporais-da-mortalidade-de-motociclistas-em-estado-do-nordeste-brasileiro-no-seculo-xxi/17281

11. Souza CDF, Paiva JPS, Leal TC, Silva LF, Machado MF, Araújo MDP. Mortality in motorcycle accidents in Alagoas (2001-2015): temporal and spatial modeling before and after the "lei seca". Rev Assoc Med Bras. 2019;65(12):1482-8.

12. Scarpetta J, Gonçalves OO. Incentivos fiscais e o aumento de custos da saúde pública: o caso da "epidemia" de motocicletas no Brasil. Rev Veredas do Direito. 2015;12(24):227-55.

13. Brasil. Ministério da Infraestrutura. DENATRAN. Frota de veículos - 2014 [cited 2020 Jan 30]. Available from: https://www.denatran.gov.br/component/content/article/115-portal-denatran/8558-frota-de-veiculos-2014. html

14. Associação Brasileira dos Fabricantes de Motocicletas. Dados do setor [Internet]. São Paulo: ABRACICLO; 2017. [cited 2020 Jan 30]. Available from: http://abraciclo.com.br/index.php?option=com content\&view=category\&layout=blog\&id=21\&ltemid=37

15. Morais Neto OL, Montenegro MMS, Monteiro RA, Siqueira Júnior JB, Silva MMA, Lima CM, et al. Mortalidade por acidentes de transporte terrestre no Brasil na última década: tendência e aglomerados de risco. Ciênc Saúde Colet. 2012;17(9):2223-36.

16. Brasil. Ministério da Infraestrutura. DENATRAN. Frota de veículos - 2018. [cited 2020 lan 30]. Available from: https://www.denatran.gov.br/component/content/article/115-portal-denatran/8558-frota-de-veiculos-2018. html

17. Rezende Neta DS, Alves AKS, Leão GM, Araújo AA. Perfil das ocorrências de politrauma em condutores motociclísticos atendidos pelo SAMU de Teresina-PI. Rev Bras Enferm. 2012;65(6):936-41.

18. lesus VF, Rocha FC, Ferreira ASS, Alves APON, Siqueira LG. Causas associadas aos acidentes de trânsito envolvendo motociclistas: revisão integrativa. Rev Enferm Centro-Oeste Mineiro. 2017;7:e1514.

19. Amorim CR, Araújo EM, Araújo TM, Oliveira NF. Acidentes de trabalho com mototaxistas. Rev Bras Epidemiol. 2012;15(1):25-37.

20. Silva MB, Oliveira MB, Fontana RT. Atividade do mototaxista: riscos e fragilidades autorreferidos. Rev Bras Enferm. 2011;64(6):1048-55. 